\title{
Potentiality of Using Mechanically Separated Meats of Nile Tilapia in Fishburgers: Chemical, Physical and Sensory Characterization
}

\author{
Denise Pinheiro Soncini da Costa ${ }^{1 \times}$ \\ https://orcid.org/0000-0002-6055-8925
}

Tania Maria Vinturin Gonçalves ${ }^{2}$

https://orcid.org/0000-0002-4232-2804

\author{
Ana Carolina Conti-Silva ${ }^{2}$ \\ https://orcid.org/0000-0002-8139-9687
}

\begin{abstract}
${ }^{1}$ Faculty of Technology of Jales - Prof. José Camargo, Jales, SP, Brazil; ${ }^{2}$ São Paulo State University (Unesp), Institute of Biosciences, Humanities and Exact Sciences (Ibilce), Department of Food Engineering and Technology, São José do Rio Preto, SP, Brazil.
\end{abstract}

Received: 2018.08.15; Accepted: 2019.07.08.

*Correspondence: denise.costa@fatec.sp.gov.br; Tel.: +55 1799704 0777; (D.P.S.C)

\section{HIGHLIGHTS}

- Fishburger with tilapia filleting by-product MSM are preferred over the carcass MSM.

- This study shows the feasibility of using tilapia filleting by-product in burgers.

- This is innovative considering the lack of studies for this MSM until now.

- The use of carcass MSM may be feasible with reformulation of the fishburger.

\begin{abstract}
Fishburgers were made with washed mechanically separated meat (MSM) from carcass and filleting by-product (both washed and unwashed) of the Nile tilapia. The proximal composition of fishburgers was different and varied according to the raw material used, as well the color parameters. Fishburgers with MSM from filleting by-product had lower hardness and springiness, and fishburger with MSM from unwashed filleting by-product had higher yield and lower reduction in thickness. The fishburgers containing MSM from filleting by-product had better sensory acceptance, due to higher color intensities (sensory), fish odor, tenderness, succulence, cohesiveness and fish flavor. The fishburger with MSM from washed carcass was the least acceptable, because of surface uniformity. This study shows the potentiality of using MSM from tilapia filleting by-product for burgers, while the formulation of fishburgers with smaller amounts of MSM from washed carcass or with added condiments can result in improved sensory acceptance and potentiality of use.
\end{abstract}

Keywords: carcass; filleting by-product; sensory profile; sensory acceptance. 


\section{INTRODUCTION}

Fish consumption per capita in Brazil is lower than $10 \mathrm{~kg} / \mathrm{year}$, while FAO's (Food and Agriculture Organization of the United Nations) recommendation is $12 \mathrm{~kg} / \mathrm{year}$ and world mean is over than $20 \mathrm{~kg} / \mathrm{year}$. Nonetheless, the aquaculture in Brazil increased $4.5 \%$ at 2018 , having tilapia as the highlight (growth of $11.9 \%$ ), allowing the country as the world's fourth largest tilapia producer [1]. Tilapia has good potential for commercialization, because the filleted steak does not contain bones and has firmer texture when compared to other species of fish, as well as it is white and succulent with a pleasant flavor. Therefore, tilapia a good option for increasing fish consumption in Brazil.

Tilapia is marketed mainly in the form of frozen fillets, the production of which generates by-products such as mechanically separated meat (MSM). The tilapia MSM can be produced from both the fish carcass and the filleting by-product, which has a ' $\mathrm{V}$ ' shaped bone. At the moment, tilapia MSM is mostly used as an ingredient in animal feed in the form of fish meal [2]. So, there is plenty of opportunity to make better use of tilapia MSM for human consumption.

Few scientific studies were found regarding the implementation of MSM from tilapia carcasses in meat products such as sausage [3], pâté [4] and burger [5,6]. No research into the use of MSM from tilapia filleting by-product for producing food for human consumption was found. Coupled to this, there is a notable absence of fish products in the Brazilian market, reinforcing the importance of using the fish by-products in food. Therefore, considering the low use of tilapia carcass MSM, and the lack of information regarding the use of MSM from filleting by-product in human foodstuff, linked to the importance of developing fish products in an attempt to increase the consumption of this food, the aim of this work was to produce fishburgers from both carcass MSM and filleting by-product MSM, followed by their chemical, physical and sensory characterization.

\section{MATERIAL AND METHODS}

\section{Material}

MSM from Nile tilapia (Oreochromis niloticus) of the GIFT (Genetically Improved Farmed Tilapia) strain, supplied by Cooperativa Agroindustrial Consolata - COPACOL (Nova Aurora, Paraná, Brazil), was used, and at least $830 \mathrm{~kg}$ of live fish, in one batch, were used for obtaining $10 \mathrm{~kg}$ of each MSM. One of the MSM was produced from the carcass, after the fillets had been removed. However, the fillet still has a "V" shaped bone, which was removed by a manual " $\mathrm{V}$ " cut, resulting in the filleting by-product, from which the other MSM is obtained.

Part of the MSM from the filleting by-product was washed at the Copacol plant itself, using water at $21^{\circ} \mathrm{C}$ for $10 \mathrm{~min}$, at a ratio of $2 / 3$ in relation to the weight $(\mathrm{v} / \mathrm{w})$, and then centrifuged at 3,600 rpm for $30 \mathrm{~s}$. Washing the MSM is a common step in processing plants, since it removes blood, pigments, sarcoplasmic proteins, lipids, ash and other nitrogen compounds, improving the sensory characteristics of texture, color and odor $[7,8]$.

The three MSMs (from washed carcass, unwashed and washed filleting by-products) were frozen in $1 \mathrm{~kg}$ portions in plastic containers and maintained at $-18^{\circ} \mathrm{C}$ until it was time to prepare the fishburgers, that was performed 6 days after the MSMs obtainment. Unwashed carcass MSM was not used in the elaboration of fishburgers due to its chemical instability which had been determined in a previous study by this research group.

\section{Fishburger production}

For each MSM formulation, 1\% (w/w) of Temperex Fish (BKG Adicon, São Bernardo do Campo, Brazil), that is a condiment for fish products, was added. Temperex Fish is composed of salt (63.1 - 69.1\%), prepared condiment (citric acid, black pepper, red pepper, sweet fennel and natural fish aroma), monosodium glutamate, and isolate soy protein. The frozen MSMs were ground in a grinder (Bermar, São José do Rio Preto, Brazil) with a $5 \mathrm{~mm}$ 
disc and then mixed with the seasoning. Then, $56 \mathrm{~g}$ of the dough (the weight of commercial hamburgers in Brazil) were weighed into a polyethylene bag, which was placed inside a petri dish and, with the aid of the petri dish lid, the fishburger was molded. The polyethylene bag with the fishburger was closed, placed inside a larger polythene bag, along with other burgers, and stocked in a freezer.

The fishburgers were stored during 120 days. During this period, samples of the fishburgers were withdrawn for performing the descriptive analysis. However, all analyses, including the final descriptive analysis, were performed at 120 days of storage. For this reason, the raw fishburgers were submitted to microbiological analysis after zero, 60 and 120 days to ensure that they were in satisfactory sanitary conditions for the sensory analysis, and all burgers were in satisfactory sanitary conditions in accordance with current legal standards.

For all analyses, frozen fishburgers were smeared with soybean oil grilled in an electric pan for $5 \mathrm{~min}$, the fishburger being turned after half the time. The geometric center of the product was kept at $74^{\circ} \mathrm{C}$ for sanitary safety [9].

\section{Analysis of the proximate composition of fishburgers}

The proximate composition was analyzed (in triplicate), moisture being measured at $60^{\circ} \mathrm{C}$ in a vacuum oven, ash content in a muffle furnace at $550 \stackrel{\circ}{\circ}$ and protein content by micro-kjeldahl (6.25 conversion factor) following the methods described in AOAC [10]. The lipid content was analyzed using the method described by Bligh and Dyer [11].

\section{Analysis of the physical properties of fishburgers}

The color was analyzed in Color Flex $45 / 0$ colorimeter (Hunterlab, Reston, USA) using a D65 illuminator, $10^{\circ}$ observer angle and the $\mathrm{CIEL}{ }^{*} \mathrm{C}^{*} \mathrm{~h}$ system $\left(\mathrm{L}^{*}=\right.$ luminosity; $\mathrm{C}^{*}=$ chroma; $\mathrm{h}=$ hue). The sample, in triplicate, was placed inside a quartz capsule with internal diameter of $58 \mathrm{~mm}$, lining it completely. Each sample was rotated every $90^{\circ}$ until all four rotations were completed, and the analysis being done on the edge and in the middle of the fishburger, thus totaling twenty-four measurements for each fishburger.

The texture analysis was performed using a TA.XT/Plus/50 texturometer (Stable Micro Systems, Godalming, England). Two samples with a diameter of $22 \mathrm{~mm}$ were cut from three fishburgers, totaling six replicates. Two tests were performed: 1) Texture Profile Analysis (TPA), with a cylindrical aluminum probe with a diameter of $36 \mathrm{~mm}, 50 \%$ of sample compression, test speed of $1 \mathrm{~mm} / \mathrm{s}$ and $5 \mathrm{~s}$ between the two compressions, to obtain the hardness, cohesiveness, springiness and chewiness parameters; and 2) cutting analysis with a Warner Bratzler blade with ' $V$ ' slot blade insert (1 $\mathrm{mm}$, USDA standard) and test speed of $1 \mathrm{~mm} / \mathrm{s}$, the sample being cut completely.

The yield of the fishburgers was calculated by the difference between the weight of the whole raw fishburger and the whole grilled fishburger, and also the reduction of the diameter and thickness of the fishburgers was measured [12]. These analyses were performed in triplicate.

\section{Analysis of the sensory profile of fishburgers}

The sensory analysis was performed at the Sensory Analysis Laboratory of the Institute of Biosciences, Literature and Exact Sciences and this study had been approved by the Ethics Committee of the same Institute (Opinion Report 919,827). The descriptive analysis was based on an adaptation of Stone and Sidel [13] and fourteen panelists (who had previously taken part in other trained panels) were invited to participate in this panel.

The sensory attributes were generated by the fourteen panelists, using the Kelly Repertory Grid method [14]. After discussions to reach consensus, the attributes that were most important for characterizing the appearance, odor, texture and flavor of the fishburger were selected. The sensory panel also defined the attributes and references for each one of these attributes (Table 1). 
Table 1. Definitions and references of the attributes of fishburgers with mechanically separated meats of tilapia.

\begin{tabular}{|c|c|c|}
\hline Attribute & Definition & References \\
\hline \multicolumn{3}{|l|}{ Appearance } \\
\hline Color & $\begin{array}{l}\text { Whitish fish color, } \\
\text { ranging from pale to } \\
\text { colored }\end{array}$ & $\begin{array}{l}\text { Pale: tilapia fillet (Copacol) cooked in microwave for } \\
\qquad \begin{array}{l}1 \text { min } 30 \text { s, at } 100 \% \text { power } \\
\text { Colored: chicken and beef burger (Texas } \\
\text { Burger-Seara), grilled in electric pan, position } 5 \text {, for } 1 \\
\text { min on each side }\end{array}\end{array}$ \\
\hline $\begin{array}{l}\text { Surface } \\
\text { uniformity }\end{array}$ & Smooth/rough surface & $\begin{array}{c}\text { Smooth: peanut fudge (Saint Helena) } \\
\text { Rough: homemade peanut fudge (Doces Leo) }\end{array}$ \\
\hline \multicolumn{3}{|l|}{ Odor } \\
\hline Fish odor & Characteristic of fish & $\begin{array}{l}\text { Weak: tilapia pâté prepared as follows: } 72 \mathrm{~g} \text { of tilapia } \\
\text { fillet (Copacol) mixed with } 1 \mathrm{~g} \text { of seasoning from BKG } \\
\text { Adicon and cooked in a microwave for } 2 \mathrm{~min} \text {, at } \\
100 \% \text { power. Thereafter, } 20 \mathrm{~g} \text { of light cream (Nestlé, } \\
\text { can) and } 7 \mathrm{~g} \text { of semi-skimmed UHT milk (Nestlé) } \\
\text { were added, by manually mixing all ingredients } \\
\text { Strong: tilapia fillet (Copacol) with } 1 \% \text { seasoning of } \\
\text { BKG Adicon, grilled in electric pan, position } 5 \text {, for } 2 \\
\text { min on each side }\end{array}$ \\
\hline \multicolumn{3}{|l|}{ Texture } \\
\hline Tenderness & $\begin{array}{l}\text { Force needed to } \\
\text { compress the burger } \\
\text { between the molars }\end{array}$ & $\begin{array}{l}\text { Little: cooked restructured pork shoulder cut into } \\
\text { cube ( } 1.5 \mathrm{~cm} \text { side) (Sadia) } \\
\text { Very: Viennese canned sausage (Bordon) cut with } \\
1.5 \mathrm{~cm} \text { high }\end{array}$ \\
\hline Succulence & $\begin{array}{l}\text { During chewing, the } \\
\text { amount of moisture } \\
\text { released by the } \\
\text { fishburger }\end{array}$ & $\begin{array}{l}\text { Little: } 1 / 2 \text { slice of shaped bread (Panco), peeled, cut } \\
\text { into } 2-\mathrm{cm} \text { side squares, moistened with milk }(3 \mathrm{~mL}) \\
\text { Very: } 1 / 2 \text { slice of shaped bread (Panco), peeled, cut } \\
\text { into } 2-\mathrm{cm} \text { side squares, moistened with milk ( } 10 \mathrm{ml})\end{array}$ \\
\hline Cohesiveness & $\begin{array}{l}\text { During chewing, the } \\
\text { degree to which the } \\
\text { pieces of the sample } \\
\text { remain cohesive }\end{array}$ & $\begin{array}{l}\text { Little: integral cookie (Jasmine) } \\
\underline{\text { Very: 'maria mole' (Bruju) }}\end{array}$ \\
\hline
\end{tabular}

Flavor

Fish flavor Characteristic flavor of

Weak: tilapia pâté prepared in the same way as for fish the 'weak' reference for the fish odor

Strong: tilapia fillet prepared in the same way as for the reference 'strong' for the fish odor

After the training stage, which took nine sessions, the panelists were selected according to their capacity to discriminate samples $\left(p_{\text {sample }} \leq 0.50\right)$, capacity to reproduce judgments ( $p_{\text {repetition }}>0.05$ ) and consensus with the panel $[15,16]$. Twelve panelists were selected to conduct the analysis on the sensory profile of the fishburgers. Among these panelists, the 
majority considered themselves to be very fond of fish and derived products and the highest frequency of consumption was at least once a week.

The sensory analysis was performed in individual booths, under white light and at a temperature of $22^{\circ} \mathrm{C}$. One quarter of each fishburger was presented on a white plastic plate coded with random three-digit numbers and were evaluated in three repetitions by the twelve panelists. The sample presentation was balanced with complete blocks that were randomized and monadic [17] and an unstructured linear intensity scale of $90 \mathrm{~mm}$ length was used for each attribute. During all the analyses of the sensory profile, the frozen fishburgers were promptly grilled, as described in Fishburger production, to be presented to the panelists.

\section{Analysis of the sensory acceptance of the burgers}

The sensory analysis was performed with ninety-nine consumers among students, employees and professors of the Institute. First, the consumers completed a questionnaire of demographic questions to specify their degree of liking and frequency of consumption of fish and fish products. Most of them like fish and fish products a lot and the highest frequency of consumption is at least once a week.

The fishburgers were then evaluated using the nine-point structured hedonic scale, with the extremes ' 1 - disliked extremely' and ' 9 - liked extremely', for appearance, odor, texture and flavor, as well as overall acceptance. A five-point scale for purchase intention ranged from 'I would certainly not buy this' to 'I would certainly buy this' [18] was also applied.

The test was conducted in individual booths, under white light, at a temperature of $22^{\circ} \mathrm{C}$. One-quarter of each fishburger was presented on white plastic plate coded with random three-digit numbers, in a monadic, balanced and random manner. The frozen fishburgers were promptly grilled, as described in Fishburger production, to be presented to the consumers.

\section{Statistical analyses}

The means were compared using analysis of variance followed by the Tukey test, at a significance level of 0.05 . Two external preference maps were constructed using principal component analysis: one correlating sensory acceptance and sensory attributes; and other correlating sensory acceptance and physical parameters. The raw data of variables were placed in the columns and the fishburgers were placed in the rows, and the data were standardized in the columns before the analysis. Factor extraction was performed from the correlation matrix and factor rotation was not used. All analyses were performed using the Statistica 10.0 software (StatSoft, Inc.).

\section{RESULTS}

\section{Proximate composition of fishburgers}

The fishburger with MSM from washed filleting by-product presented the lowest levels of proteins and ash, probably due to the higher moisture in relation to the other fishburgers (Table 2). However, the burger with carcass MSM was the one that presented the lowest lipid content. Furthermore, the washing process for the filleting changed the proximate composition of the fishburgers, increasing the moisture and lipid content, as well as reducing the contents of proteins and ashes. 
Table 2. Proximate composition (mean \pm standard deviation; $n=3$ ) of fishburgers with mechanically separated meats of tilapia.

\begin{tabular}{cccc}
\hline $\begin{array}{c}\text { Component } \\
(\mathbf{g} / \mathbf{1 0 0} \mathbf{g})\end{array}$ & $\begin{array}{c}\text { Washed } \\
\text { carcass }\end{array}$ & $\begin{array}{c}\text { Unwashed filleting } \\
\text { by-product }\end{array}$ & $\begin{array}{c}\text { Washed filleting } \\
\text { by-product }\end{array}$ \\
\hline Moisture & $72.4 \pm 0.24^{\mathrm{b}}$ & $70.5 \pm 0.09^{\mathrm{a}}$ & $73.9 \pm 0.07^{\mathrm{c}}$ \\
Ash & $1.9 \pm 0.07^{\mathrm{b}}$ & $1.9 \pm 0.03^{\mathrm{b}}$ & $1.6 \pm 0.17^{\mathrm{a}}$ \\
Proteins & $21.1 \pm 0.35^{\mathrm{c}}$ & $20.0 \pm 0.19^{\mathrm{b}}$ & $16.9 \pm 0.18^{\mathrm{a}}$ \\
Lipids & $3.8 \pm 0.16^{\mathrm{a}}$ & $6.1 \pm 0.07^{\mathrm{b}}$ & $6.6 \pm 0.13^{\mathrm{c}}$ \\
\hline
\end{tabular}

Different letters in the same row indicate significant difference by Tukey test $(p \leq 0.05)$.

\section{Physical properties of fishburgers}

The burgers with MSM from filleting by-product (with and without washing) presented higher $C^{*}$ than the fishburger made with carcass MSM (Table 3 ). Furthermore, washed filleting by-product MSM led to an increased $L^{*}$ of the burger, i.e. the color of the burger became clearer. Thus, the hues were different for the three fishburgers, increasing from the unwashed filleting by-product MSM burger to the washed carcass MSM. However, all fishburgers may have the color classified as yellow, because angles from 70 to $100^{\circ}$ indicate a predominance of yellow chromaticity over red chromaticity [19]. There were no reports in the literature regarding the texture of MSM tilapia burgers to compare these results with.

Table 3. Color $(n=24)$, texture $(n=6)$ and preparation characteristics $(n=3)$ of fishburgers with mechanically separated meats of tilapia (mean \pm standard deviation).

\begin{tabular}{cccc}
\hline Characteristics & $\begin{array}{c}\text { Washed } \\
\text { carcass }\end{array}$ & $\begin{array}{c}\text { Unwashed filleting } \\
\text { by-product }\end{array}$ & $\begin{array}{c}\text { Washed filleting } \\
\text { by-product }\end{array}$ \\
\hline $\begin{array}{c}\text { Color } \\
\mathrm{L}^{*}\end{array}$ & $58.1 \pm 1.13^{\mathrm{b}}$ & $56.6 \pm 3.46^{\mathrm{a}}$ & $63.4 \pm 1.29^{\mathrm{c}}$ \\
$\mathrm{C}^{*}$ & $15.6 \pm 2.93^{\mathrm{a}}$ & $24.3 \pm 2.21^{\mathrm{b}}$ & $23.1 \pm 1.19^{\mathrm{b}}$ \\
$\mathrm{h}\left(^{\mathrm{o}}\right)$ & $84.8 \pm 1.98^{\mathrm{c}}$ & $74.1 \pm 2.80^{\mathrm{a}}$ & $78.3 \pm 1.79^{\mathrm{b}}$ \\
\hline Texture & & & $10.0 \pm 1.77^{\mathrm{a}}$ \\
Hardness (N) & $45.2 \pm 3.74^{\mathrm{c}}$ & $29.0 \pm 5.55^{\mathrm{b}}$ & $0.7 \pm 0.03^{\mathrm{b}}$ \\
Cohesiveness & $0.6 \pm 0.03^{\mathrm{a}}$ & $0.6 \pm 0.02^{\mathrm{a}}$ & $0.4 \pm 0.09^{\mathrm{a}}$ \\
Springiness & $0.7 \pm 0.03^{\mathrm{c}}$ & $0.6 \pm 0.07^{\mathrm{b}}$ & $1.8 \pm 0.54^{\mathrm{a}}$ \\
Chewiness & 20.4 & 10.1 & $64.6 \pm 3.78^{\mathrm{a}}$ \\
Cutting force (N) & $2.9 \pm 0.66^{\mathrm{b}}$ & $2.2 \pm 0.36^{\mathrm{ab}}$ & $11.0 \pm 1.75^{\mathrm{ns}}$ \\
\hline $\begin{array}{c}\text { Preparation } \\
\text { Yield }\end{array}$ & $67.0 \pm 2.27^{\mathrm{a}}$ & $82.7 \pm 1.55^{\mathrm{b}}$ & \\
Reduction in the & $10.3 \pm 1.24^{\mathrm{ns}}$ & $8.0 \pm 1.29^{\mathrm{ns}}$ & $27.9 \pm 2.53^{\mathrm{c}}$ \\
diameter & & & \\
Reduction in the & $17.3 \pm 1.77^{\mathrm{b}}$ & $10.0 \pm 2.09^{\mathrm{a}}$ & \\
thickness & & & \\
\hline
\end{tabular}

Different letters in the same row indicate significant difference by Tukey test $(p \leq 0.05)$. ns $=$ not significant.

There was a decrease in hardness, springiness and chewiness in the sequence: washed carcass MSM burger, unwashed filleting by-product and washed filleting by-product (Table 3). This indicates that the fishburger with washed filleting by-product MSM is less hard, less elastic and requires less chewing to be swallowed. Regarding the cohesiveness, 
the fishburger with washed filleting MSM presented greater cohesiveness, indicating the greater force necessary to break it when being bitten. There was also a reduction in cutting force for the carcass MSM fishburger compared with the washed filleting by-product MSM burger, while the burger with unwashed filleting by-product MSM presented a cutting force equal to the other burgers.

In relation to the characteristics for the preparation of the fishburger, the fishburger prepared with MSM from unwashed filleting by-product had higher yield and smaller reduction in the thickness after grilling (Table 3). Furthermore, the reduction in diameter was the same for all fishburgers.

\section{Sensory profile of fishburgers}

Filleting by-product MSM fishburgers showed higher intensities for color, fish odor, tenderness, succulence, cohesiveness and fish flavor compared to the fishburger with washed carcass MSM (Table 4), although had no significant difference for color, surface uniformity, tenderness and succulence. On the other hand, the fishburger with washed carcass MSM presented the highest surface uniformity and all the fishburgers were not described in unpleasant terms, such as odor and rancid flavor.

Table 4. Intensity of attributes (mean \pm standard deviation; $n=36$ ) of fishburgers with mechanically separated meats of tilapia.

\begin{tabular}{cccc}
\hline Attribute & $\begin{array}{c}\text { Washed } \\
\text { carcass }\end{array}$ & $\begin{array}{c}\text { Unwashed filleting } \\
\text { by-product }\end{array}$ & $\begin{array}{c}\text { Washed filleting } \\
\text { by-product }\end{array}$ \\
\hline $\begin{array}{c}\text { Color } \\
\text { Surface uniformity }\end{array}$ & $1.9 \pm 0.73^{\mathrm{a}}$ & $6.3 \pm 1.40^{\mathrm{b}}$ & $5.7 \pm 1.30^{\mathrm{b}}$ \\
Fish odor & $1.9 \pm 0.40^{\mathrm{b}}$ & $2.0 \pm 1.57^{\mathrm{a}}$ & $1.9 \pm 0.46^{\mathrm{a}}$ \\
Tenderness & $2.5 \pm 1.06^{\mathrm{a}}$ & $6.9 \pm 0.80^{\mathrm{c}}$ & $6.5 \pm 0.66^{\mathrm{b}}$ \\
Succulence & $2.5 \pm 0.95^{\mathrm{a}}$ & $7.1 \pm 0.48^{\mathrm{b}}$ & $6.7 \pm 0.67^{\mathrm{b}}$ \\
Cohesiveness & $2.0 \pm 0.80^{\mathrm{a}}$ & $7.0 \pm 0.60^{\mathrm{b}}$ & $6.8 \pm 0.68^{\mathrm{b}}$ \\
Fish flavor & $2.4 \pm 1.14^{\mathrm{a}}$ & $6.7 \pm 0.73^{\mathrm{c}}$ & $6.2 \pm 0.89^{\mathrm{b}}$ \\
\hline
\end{tabular}

Different letters in the same row indicate significant difference by Tukey test $(p \leq 0.05)$.

\section{Sensory acceptance of fishburgers}

The washed carcass MSM burger was less accepted than the burgers with filleting by-product MSM with respect to all the attributes and overall acceptance, getting between the hedonic categories 'not liked nor disliked' and 'liked slightly', and the categories of 'I probably would not buy this' and 'I doubt whether or not I would buy this' (Table 5). Both burgers with filleting by-product MSM were equally accepted for appearance, odor and texture, falling into the categories 'liked moderately' to 'liked very much' for the appearance, and between the categories 'liked slightly' and 'liked very much' for odor and texture. However, the fishburger with unwashed filleting by-product MSM had greater acceptance of the flavor and of global form in relation to the fishburger with washed filleting by-product MSM, according to the hedonic scale and the scale of purchase intention, being between the categories 'liked moderately' and 'liked very much' and between the categories 'I would probably buy this' and 'I would certainly buy this', respectively. 
Table 5. Sensory acceptance (mean \pm standard deviation; $n=99$ ) of fishburgers with mechanically separated meats of tilapia.

\begin{tabular}{cccc}
\hline Acceptance & $\begin{array}{c}\text { Washed } \\
\text { carcass }\end{array}$ & $\begin{array}{c}\text { Unwashed filleting } \\
\text { by-product }\end{array}$ & $\begin{array}{c}\text { Washed filleting } \\
\text { by-product }\end{array}$ \\
\hline Appearance & $5.2 \pm 1.87^{\mathrm{a}}$ & $7.2 \pm 1.44^{\mathrm{b}}$ & $7.1 \pm 1.31^{\mathrm{b}}$ \\
Odor & $5.5 \pm 1.91^{\mathrm{a}}$ & $7.3 \pm 1.39^{\mathrm{b}}$ & $6.9 \pm 1.38^{\mathrm{b}}$ \\
Texture & $6.0 \pm 1.84^{\mathrm{a}}$ & $7.3 \pm 1.59^{\mathrm{b}}$ & $6.8 \pm 1.46^{\mathrm{b}}$ \\
Flavor & $5.2 \pm 1.92^{\mathrm{a}}$ & $7.7 \pm 1.33^{\mathrm{c}}$ & $6.9 \pm 1.55^{\mathrm{b}}$ \\
Overall & $5.3 \pm 1.77^{\mathrm{a}}$ & $7.5 \pm 1.23^{\mathrm{c}}$ & $6.8 \pm 1.43^{\mathrm{b}}$ \\
$\begin{array}{c}\text { acceptance } \\
\text { Purchase }\end{array}$ & $2.6 \pm 1.06^{\mathrm{a}}$ & $4.1 \pm 0.94^{\mathrm{c}}$ & $3.6 \pm 1.00^{\mathrm{b}}$ \\
intention & & & \\
\hline
\end{tabular}

Different letters in the same row indicate significant difference by Tukey test $(p \leq 0.05)$.

The sensory acceptance correlated with the sensory profile of the fishburgers. The first and second principal components explained 67.6 and $18.6 \%$ of the observed variation, respectively, totaling $86.2 \%$ of the total data variation (Figure 1). The first principal component was explained by two groups of variables (Figure 1A): one composed by the acceptance of flavor, overall acceptance, purchase intention, color, fish odor, tenderness, succulence, cohesiveness and fish flavor (factorial charges $\leq-0.70$ in principal component 1 ); and the other composed by the surface uniformity surface (factorial charge $\geq 0.70$ in principal component 1 ). This means that the surface uniformity correlated negatively with the other variables, whose correlations were positive with each other. The acceptance of appearance, odor and texture did not discriminate any of the samples and no variables explained principal component 2.

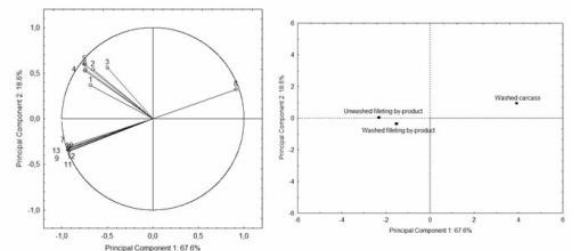

Figure 1. External preference mapping between sensory acceptance and sensory attributes of fishburgers with mechanically separated meats of tilapia (A - Projection of variables, B - Projection of fishburgers). Legend: Acceptance (1 - appearance, 2 - odor, 3 - texture, 4 - flavor, 5 - overall acceptance, 6 - purchase intention) and sensory attributes ( 7 - color, 8 - surface uniformity, 9 - fish odor, 10 - tenderness, 11 - succulence, 12 - cohesiveness, 13 - fish flavor).

The burgers containing washed and unwashed filleting by-product MSM were described by the sensory acceptance of flavor, overall acceptance and purchase intention, result of the high intensities of color, fish odor, tenderness, succulence, cohesiveness and fish flavor (Figure 1B). On the other hand, the fishburger with washed carcass MSM was highlighted by the surface uniformity, in addition to the low sensory acceptance.

Sensory acceptance also correlated with the physical properties of tilapia MSM burgers. The first and second principal components explained, respectively, 45.2 and $32.6 \%$ of the variance observed, totaling $77.8 \%$ of the total data variation (Figure 2 ). The first principal component was explained by two groups of variables (Figure $2 \mathrm{~A}$ ): one composed by the hardness, springiness, chewiness, cutting force, and $\mathrm{h}$ (factorial charges $\geq 0.68$ also in principal component 1 ), and another composed by overall acceptance, $\mathrm{C}^{*}$ and cohesiveness (factorial charges $\leq-0.68$ in principal component 1 ). The second principal component was also explained by two groups of variables: one made up of yield (factorial charge $\geq 0.70$ in 
principal component 2) and another composed of reduction of diameter, reduction of thickness and $L^{*}$ (factorial charges $\leq-0.70$ also in principal component 2 ).

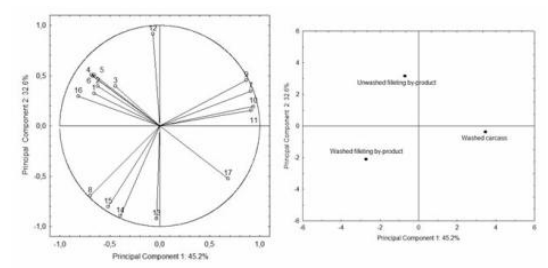

Figure 2. External preference mapping between sensory acceptance and physical properties of fishburgers with mechanically separated meats of tilapia (A - Projection of variables, B - Projection of fishburgers). Legend: Acceptance (1 - appearance, 2 - odor, 3 - texture, 4 - flavor, 5 - overall acceptance, 6 - purchase intention) and physical properties and preparation characteristics (7 hardness, 8 - cohesiveness, 9 - springiness, 10 - chewiness, 11 - cutting force, 12 - yield, 13 - diameter reduction, 14 - thickness reduction, $\left.15-L^{*}, 16-C^{*}, 17-h\right)$.

The burgers were described differently (Figure 2B). The fishburger with washed carcass MSM was distinguished by the high intensities of hardness, springiness, chewiness, cutting force and hue. The burger with unwashed filleting by-product MSM was described by overall acceptance, $\mathrm{C}^{*}$ and cohesiveness, as well as high yield, although there is no correlation between the yield and the other characteristics, since they are in separate principal components. And the burger with washed filleting by-product MSM was described by reduction in diameter, reduction of thickness and $L^{*}$ (clearer color).

Thus, the external preference mapping show the characteristics related to the greater or lower acceptance of the fishburgers by the consumers, besides corroborating and summarizing the results presented in Tables 2 to 5 .

\section{DISCUSSION}

Changes on the proximal composition were found in function of the washing (Table 2). The increase in the moisture of fishburgers is because the washing removes sarcoplasmic proteins, while the myofibrillar proteins, which have the capacity to retain water, remain in the MSM [7]. Also, the removal of the sarcoplasmic proteins reduced the protein content in the MSM. On the other hand, the reduction of ash content is explained by leaching, which removes some of the minerals in the MSM [20]. Only one study was found in the scientific literature regarding the use of tilapia MSM for fishburger production, in which case the fishburger was produced with washed carcass MSM. The raw burger had a higher moisture value $(75.3 \%)$ and lipids (4.7\%) compared to those found in the present study but less proteins (18.2\%) [6]. Probably the differences are in the fact that the fishburger had the addition of $5 \%$ soy protein and $3 \%$ canola oil in its formulation. However, the amount of ash $(2.1 \%)$ is close to the amount found in the current research.

The legislation on beef, pork, turkey or chicken burgers [21] regulates a maximum fat content of $23 \%$ and minimum protein of $15 \%$. Although there is no Brazilian legislation for fishburgers, the three burgers in this study are within the legislation for hamburgers from other animals.

Regarding the physical properties, the reduction of the hardness and cutting force of the unwashed filleting by-product MSM burger compared to the washed filleting by-product MSM burger is due to the loss of water soluble proteins [22], which is actually seen in Table 2. And so, there is a greater hardness for the fishburger with washed carcass MSM and also higher protein content. In addition, the values of hardness and cutting force of the fishburgers decreased with the increase in the lipid content (Table 2), showing the contribution of this component to the tenderness of the product [23]. The higher yield and smaller reduction in the thickness to the fishburger prepared with MSM from unwashed filleting by-product (Table 3) may be explained by the lower moisture loss after the grilling process. Considering the moisture values of raw fishburgers (not shown), the loss of water of the fishburgers during grilling was $11.4,8.8$ and $12.4 \%$ for burgers with washed carcass 
MSM, unwashed filleting by-product MSM and with washed filleting by-product MSM, respectively. Thus, the lowest water loss $(8.8 \%)$ during the grilling of the fishburger with unwashed filleting by-product MSM may have resulted in higher yield and less reduction in its thickness. Still, the largest thickness reduction for the burger with washed filleting by-product MSM coincides with the largest water loss (12.4\%).

Filleting by-product MSM fishburgers showed higher intensities for color, fish odor, tenderness, succulence, cohesiveness and fish flavor compared to the fishburger with washed carcass MSM (Table 4), and such differences are related to other characteristics of the MSM and the burgers themselves. The filleting by-product MSM burgers presented color with higher $\mathrm{C}^{*}$ in relation to the burger with carcass MSM (Table 3), as well as sensory evaluated color. The higher intensities for odor and fish flavor in fishburgers with filleting by-product MSM may be because this MSM present a larger amount of meat while the carcass MSM has more bone. Larger intensities for tenderness and succulence are related to the lower values of hardness and cutting force of the burgers with MSM of filleting (Table 3). And again, the fact that the filleting by-product MSM presents more meat may have contributed to the greater succulence and cohesiveness intensities of the burgers.

The unwashed filleting by-product MSM burger had higher intensities for fish odor, cohesiveness and fish flavor (Table 4), probably because the washing diminished the odor and flavor of fish $[7,8]$. This reducing may be also responsible for the higher acceptance of flavor and of global form in relation to the fishburger with washed filleting by-product MSM (Table 5). And for the fishburger with washed carcass MSM, the highest surface uniformity (Table 4) may be due to the greater presence of bone and smaller quantity of meat in the MSM, which may have led to a greater uniformity of the MSM after pressing by resulting in greater uniformity of the burger.

No studies were found in the scientific literature describing the sensory profile of fishburgers formulated with tilapia carcass MSM and tilapia filleting by-product MSM. However, for fishburgers made from unwashed ground fillet and fillet washed three times from Serra Spanish Mackerel (Scomberomorus brasiliensis), the attributes defined by trained panelists were: crust color, fish shape, thickness, quantity of herbs, minced fish color fish aroma, aroma of artificial flavor, salty taste, umami taste, fish flavor, herb flavor, residual artificial flavor, hardness, crunchiness, tenderness, succulence and cohesiveness [24]. It should be noted that several attributes are similar to those described in the present work. However, the majority of the attributes are the result of the addition of various condiments (salt, monosodium glutamate, textured soy protein, corn starch, garlic and onion powder, parsley and chives) in the formulations of fishburgers, different from our work, in which the fishburgers were formulated almost exclusively with MSM. Also, unlike the current work, the fillet washing diminished the color intensity and increased the tenderness for some fishburgers.

In relation to sensory acceptance, several studies in the literature report on the sensory acceptance of fishburgers formulated with carcass MSM from different fishes $[5,25,26]$, and the acceptance averages were higher than those found in this study for the washed carcass MSM burger. However, one can attribute these higher averages as a result of the addition of several ingredients in the burgers produced in the cited study, in contrast to our work, which only had $1 \%$ of condiment (see Fishburger production). Also, no studies were found regarding the sensory acceptance of fishburgers formulated with tilapia filleting by-product MSM.

\section{CONCLUSION}

This study shows the potentiality of using tilapia filleting by-product in burgers, which is innovative considering that the raw material is a by-product that can be an added almost exclusively to the fishburger (i.e. with little seasoning), as well the lack of studies in the literature for this MSM until up to the present. In relation to the burger made with washed carcass MSM, again it should be noted that it was also formulated almost exclusively from the MSM, which may have contributed to its low sensory acceptance. Thus, the formulation 
of burgers with smaller amounts of washed carcass or added condiments, could result in improved sensory acceptance and potentiality of use, also adding value to this MSM.

\section{REFERENCES}

1. Medeiros, F. ANUÁRIO Peixe BR da Piscicultura 2019. [internet]. São Paulo: 2019. (cited 2019 Mar 19). Available from: http://www.peixebr.com.br

2. Glencros, BD, Booth M, Allan GL. A feed is only as good as its ingredients - a review of ingredient evaluation strategies for aquaculture feeds. Aquac Nutrition. 2007;13:17-34.

3. Oliveira Filho PRC, Maria Netto F, Ramos KK, Trindade MA, Viegas EMM. Elaboration of sausage using minced fish of Nile tilapia filleting waste. Braz Arch Biol Technol. 2010;53:1383-91.

4. Freitas DGC, Resende ALSS, Furtado AAL, Tashima L, Bechara HM. The sensory acceptability of a tilapia (Oreochromis niloticus) mechanically separated meat-based spread. Braz J Food Technol. 2012;15:166-73.

5. Mello SCRP, Freitas MQ, São Clemente SC, Franco RM. Development and bacteriological, chemical and sensory characterization of fishburgers made of Tilapia minced meat and surimi. Arq Bras Med Vet Zootec. 2012;64:1389-97.

6. Mélo HMG, Galvão SMR, Silva JG, Maciel MIS, Moreira RT, Andrade SAC, Mendes ES. The fish burger quality of mechanically recovered meat from tilapia using added wheat fibre and corn oil. ARS Vet. 2014;30:23-31.

7. Park JW, Lin TM. Surimi: manufacturing and evaluation. In Surimi and surimi seafood. 2nd ed. Park JW, editor. London (UK): Taylor and Francis Group, CRC; 2005. p. 33-10.

8. Gonçalves AA, Passos MG. Restructured fish product from white croacker (Micropogonias furnieri) mince using microbial transglutaminase. Braz Arch Biol Technol. 2010;53:987-95.

9. Brasil. CVS Portaria 5, 9 April, 2013. Regulamento técnico sobre boas práticas para estabelecimentos comerciais de alimentos e para serviços de alimentação. Center of Sanitary Surveillance. 9 April 2013.

10. AOAC. Official Methods of Analysis of the Association of Official Agriculture Chemists International. 17th ed. Washington (USA): AOAC International; 2000.

11. Bligh EG, Dyer WJ. A rapid method of total lipid extraction and purification. Can $\mathrm{J}$ Biochem Physiol. 1959;46:31-7.

12. Berry BW. Low fat level effects on sensory, shear, cooking and chemical properties of ground beef patties. J Food Sci. 1992;57:537-40.

13. Stone H, Sidel JL. Sensory Evaluation Practices. 3rd ed. New York (USA): Academic Press; 2004.

14. Moskowit, HR. Product Testing and Sensory Evaluation of Foods. Westport (USA): Food \& Nutrition Press; 1983.

15. American Society for Testing and Material (ASTM). Guidelines for the Selection and Training of Sensory Panel Members. ASTM Sp. Tech. Publ. no 758. 1981

16. Damasio MH, Costell E. Analisis sensorial descriptivo: generatión de descriptores y selección de catadores. Rev Agroquim Tecnolog Aliment. 1991;31:165-78.

17. Macfie HJ, Bratchell N, Greenhoff K, Vallis LV. Designs to balance the effect of order presentation and first-order carry-over effects in hall tests. J Sens Stud. 1989;4:129-48.

18. Meilgaard M, Civille GV, Carr BT. Sensory Evaluation Techniques. 4th ed. Boca Raton (USA): CRC Press; 2006.

19. Ramos EM, Gomide LAM. Avaliação da Qualidade de Carnes: Fundamentos e Metodologias. Viçosa (Brazil): UFV; 2009.

20. Borderias AJ, Tejeda M. El "surimi". Rev Agroquim Tecnolog Aliment. 1987;27:1-14.

21. Brasil. Instrução Normativa $N^{\circ} 20$, de 31 de july de 2000 . Regulamento Técnico de Identidade e Qualidade de Hambúrguer [Internet]. Ministry of Agriculture, Livestock and Food Supply. Available from: www.agricultura.gov.br. 31 july 2000. 
22. Willes JL, Green BW, Bryant R. Texture profile analysis and composition of a minced catfish product. J Texture Stud. 2004;35:325-7.

23. Garcia ML, Caceres E, Selgas MD. Utilisation of fruit fibres in conventional and reduced-fat cooked-meat sausages. J Sci Food Agric. 2007;87:624-31.

24. Quadros DA, Rocha IFO, Ferreira SMR, Bolini HMA. Low-sodium fish burgers: Sensory profile and drivers of liking. LWT Food Sci Technol. 2015;63:236-42.

25. Durães JP, Oliveira Filho PRC, Balieiro JCC, Del Carratore CR, Viegas EMM. The stability of frozen minced african catfish. J Food Sci. 2012;24:61-9.

26. Vanitha M, Dhanapal K, Reddy GVS. Quality changes in fish burger from Catla (Catla Catla) during refrigerated storage. J Food Sci Technol. 2015;52:1766-71.

(c) 2018 by the authors. Submitted for possible open access publication under the terms and conditions of the Creative Commons Attribution (CC BY NC) license (https://creativecommons.org/licenses/by-nc/4.0/). 